[Research Paper]

\title{
$\mathrm{FDS}$ 를 이용한 랙크식 창고의 화재감지 개선에 관한 연구
}

\author{
최기옥 - 박문우 $*$ 최돈묵 ${ }^{*}$
}

한국화재보험협회 부설 방재시험연구원 책임연구원, "한국화재보험협회 부설 방재시험연구원 선임연구원,

**가천대학교 설비·소방공학과 교수

\section{Improvement of Fire Detection in Rack-type Warehouses using FDS}

\author{
Ki-Ok Choi $\cdot$ Moon-Woo Park ${ }^{*}$ Don-Mook Choi ${ }^{* * \dagger}$ \\ Head Researcher, Fire Insurers Laboratories of Korea, "Senior Researcher, Fire Insurers Laboratories of Korea, \\ ${ }^{* *}$ Professor, Dept. of Building Equipment System \& Fire Protection Eng. Gachon Univ.
}

(Received August 23, 2019; Revised September 11, 2019; Accepted September 17, 2019)

\section{요 약}

랙크식 창고에서 화재가 발생되는 경우 건물이 전소되거나 붕괴되는 상태까지 발생된다. 이러한 현상이 발생되는 이유는 랙크식 창고가 층고가 높고, 물품을 수직으로 적재하고 있어 화재 시 천장에 설치되어 있는 감지기에 의한 조기감지가 어렵고, 그로 인하여 초기에 소화하지 못하기 때문이다. 본 연구에서는 수치해석 프로그램인 Fire dynamic simulator (FDS)를 이용하여 랙크식 창고 내에서 화재 시 발생되는 열과 연기의 유동을 분석하였다. 이러한 분석을 통하여 랙크식 창고 내에서 조기 화재감지를 위한 화재감지기의 최적 설치조건을 확인하였다. 그 결과 랙크 식 창고에서 조기 화재감지를 위하여 열과 연기의 복합적인 감지가 필요하며, 복합형 감지기를 랙크의 3 level 마다 설치해야 하며, 정온식 감지기는 랙크식 창고에 적합하지 않은 것을 알 수 있었다.

\section{ABSTRACT}

The occurrence of fire in rack-type warehouses may either lead to the warehouses getting entirely burned up or collapsing. This can be attrubuted to the high height of rack-type warehouses, in which combustibles are generally vertically stacked. These characteristics make it difficult to detect a fire early; because detectors are installed on the ceiling, these fires cannot be extinguished at an early stage. In this study, the flow of heat and smoke generated by a fire in a rack-type warehouse was analyzed using a fire dynamic simulator. Through this analysis, the optimal installation conditions of fire detectors for the early detection of fire in rack-type warehouses were confirmed. The analysis results confirmed that complex detection of heat and smoke is required for the early detection of fire in rack type warehouses. Furthermore, it was found that fixed temperature detectors are not suitable for these warehouses, resulting in the need to install heat-smoke hybrid detectors at every three rack levels.

Keywords : Rack, Warehouse, Fire detector, Early detection, FDS

\section{1. 서 론}

소비자들의 구매 성향이 다양해지고, 신속한 배송에 대 한 욕구가 강해짐에 따라 소비자의 대다수가 거주하는 대 도시 주변을 중심으로 물류창고가 증가하고 있으며, 그 규 모 또한 확대되고 있다. 이러한 물류창고는 대부분 수직으 로 랙크를 설치하고, 물품을 랙크의 각 단에 조밀하게 적재 하여 좁은 공간을 효율적으로 사용할 수 있는 랙크식 창고 형태로 건축되고 있다. 하지만 랙크식 창고는 층고가 높고,
물품을 수직으로 조밀하게 적재하고 있어 화재발생 시 조 기에 화재를 감지하기에 어려움이 있다. 물류창고를 포함 하여 현재 우리나라의 건축물에는 자동화재탐지설비 및 시 각경보장치의 화재안전기준(NFSC 203)에 따라 화재감지기 가 설치되어 있어도, 실제 화재 시 조기에 화재를 감지하지 못해 대형화재로 확대되는 경우가 많다 ${ }^{(1)}$. 최근 국내에서 발 생된 아모레퍼시픽 매스코스메틱 화재사고와 한국타이어 화재사고를 보면 랙크식 창고에서 화재가 발생되면 건물이 전소되거나 붕괴되는 상태까지 진행되는 것을 알 수 있다.

${ }^{\dagger}$ Corresponding Author, E-Mail: fire@gachon.ac.kr. TEL: +82-31-750-5716, FAX: +82-31-750-8749

(c) 2019 Korean Institute of Fire Science \& Engineering. All right reserved. 
$\mathrm{FDS}$ 를 이용하여 창고의 화재를 해석한 논문 중 최정아 는 $\mathrm{FDS}$ 를 이용하여 전기실의 화재특성 과 연소 생성물의 확산특성을 분석하였다(1) 또한 박원희는 철도터널의 화재 감지기 성능시험 방법을 정립하기 위하여 터널의 상부에 설치된 화재감지기의 감지특성을 $\mathrm{FDS}$ 를 이용하여 해석하 였다(2). 위에서 보는 것과 같이 $\mathrm{FDS}$ 를 이용하여 랙크식 창 고에서 열 - 연기의 유동을 분석하고, 화재감지기의 최적 설치조건에 대한 논문은 없는 실적이다.

이에 본 연구에서는 수치해석 프로그램인 FDS를 이용하 여 랙크식 창고 내에서 규격화된 화원에 의해 발생되는 열 과 연기의 유동현상을 분석하고, 이러한 분석을 통하여 랙 크식 창고에서 조기 화재감지를 위한 최적 화재감지 방안 을 제시하고자 한다.

\section{2. 화재시뮬레이션 모델링}

\section{1 화재시뮬레이션 모델링 개요}

FDS 프로그램은 Large eddy simulation (LES) 난류해석 기법에 기초하여 기본적으로 열 그리고 물질유동과 함께 화재현상을 해석하는 다양한 모델과 편리한 인터페이스를 제공한다 (3). 본 연구에서는 규격화된 화원인 n-heptane과 면 심지의 연소로 인해 발생되는 열과 연기의 유동현상을 분 석하기 위하여 화재해석 분야에서 폭 넓게 사용되고 있는 $\mathrm{FDS}$ 를 사용하였다. 구체적으로 FDS 6.7.0 Version을 사용 하였으며, FDS의 구동 툴인 Pyrosim을 이용하여 화재시뮬 레이션을 모델링하였다.

$\mathrm{FDS}$ 를 이용한 화재시뮬레이션의 결과는 화원의 크기와 격자의 크기에 따라 다르게 나타날 수 있다. 이러한 이유로 ISO 7240-9에 규격화된 n-heptane과 면심지 화원에 대한 격 자의 민감도를 분석한 후 동일 화원에서 발생된 열과 연기 의 유동을 분석하였다.

\section{2 격자민감도 분석}

$\mathrm{FDS}$ 를 이용하여 화재시뮬레이션을 수행하는 과정에서 시뮬레이션의 결과에 대한 신뢰성을 높이기 위하여 시뮬레 이션 공간의 격자크기를 화원의 크기와 특성에 적합하게 설정할 필요가 있다. 격자의 신뢰도 평가 시 가장 널리 사 용되는 방법은 NUREG-1824 보고서에서 언급된 무차원특 성길이(D*)를 기준으로 하는 것이다(4). 무차원특성길이는 주변공기 밀도, 주변공기 비열, 주변공기의 온도, 중력가속 도 그리고 열방출률에 의해 결정된다. 무차원특성길이에 대한 식은 아래의 식(1)과 같다모.

$$
D^{*}=\left[\frac{Q^{*}}{\rho_{\infty} \cdot C_{P} \cdot T_{\infty} \cdot \sqrt{g}}\right]^{\frac{2}{5}}
$$

$$
\begin{array}{ll}
D^{*} & : \text { Characteristic fire diameter } \\
\rho_{\infty} & \text { : 주변공기 밀도 }\left(\mathrm{kg} / \mathrm{m}^{3}\right) \\
C_{p} & : \text { 주변공기 비열 }(\mathrm{kJ} / \mathrm{kg} \cdot \mathrm{K}): \\
T_{\infty} & : \text { 주변공기 온도 }(\mathrm{K}) \\
g & : \text { 중력가속도 }\left(\mathrm{m} / \mathrm{s}^{2}\right) \\
Q^{*} & : \text { 열방출률 }(\mathrm{kW})
\end{array}
$$

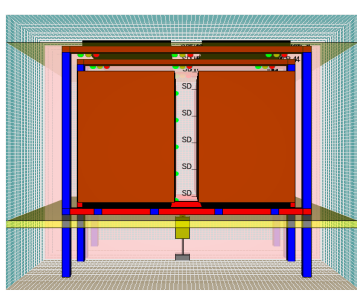

(a) Cotton wick

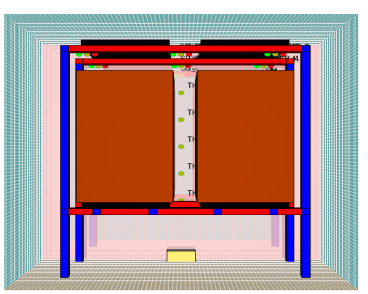

(b) N-heptane
Figure 1. Modeling for grid sensitivity analysis.

본 연구에서는 면심지를 이용한 훈소와 n-heptane을 이 용한 화염화재 각각에 대하여 격자민감도를 분석하였다. Figure 1에서 보는 것과 같이 면심지와 $364 \mathrm{~kW} \mathrm{n-heptane} \mathrm{화}$ 원에 대한 격자민감도를 분석하기 위하여 가로 $4 \mathrm{~m}$, 세로 4 $\mathrm{m}$, 높이 $4 \mathrm{~m}$ 인 시뮬레이션 공간에 1 단 랙크 구조물과 철재 더미를 모델링 하였다. 면심지와 n-heptane 각각의 화원에 서 발생되는 연기와 열 화원에 적합한 격자크기를 선정하 기 위하여 격자의 크기를 $0.5 \mathrm{~m}$ 에서 $0.05 \mathrm{~m}$ 까지 좁혀가며 격자민감도 시뮬레이션을 수행하였다. 이때 시뮬레이션 공 간의 바닥은 열기류에 대하여 비활성 면인 'INERT'로 설정 하였고, 나머지 측면과 상부의 5 개면은 연기와 열기류의 유동이 자유로운 ' $\mathrm{OPEN}$ '으로 설정하였다.

Table 1은 격자민감도 시뮬레이션의 입력조건을 나타낸 것이다. 훈소의 격자민감도 시뮬레이션에서 화원은 $0.2 \mathrm{~m}$ $(\mathrm{X}) \times 0.2 \mathrm{~m}(\mathrm{Y}) \times 0.4 \mathrm{~m}(\mathrm{Z})$ 크기의 면심지에 반지름 0.01 $\mathrm{m}$, 길이 $0.15 \mathrm{~m}$ 의 $1,000{ }^{\circ} \mathrm{C}$ Ignitor를 접촉시켜 구현하였다. $0.5 \mathrm{~m}$ 부터 $0.05 \mathrm{~m}$ 까지 격자의 크기를 좁혀가며 시뮬레이션 수행 후 $180 \mathrm{~s}$ 시점에서 바닥으로부터 $3.6 \mathrm{~m}$ 위치에서 연기 농도를 측정하였으며, 연기농도가 안정화되는 시점의 격자 크기를 연기감지 시뮬레이션의 격자크기로 선정하였다. 또 한 화염화재의 격자민감도 시률레이션에서는 $0.4 \mathrm{~m}(\mathrm{X}) \times$ $0.4 \mathrm{~m}(\mathrm{Y}) \times 0.1 \mathrm{~m}(\mathrm{Z})$ 크기의 화조에 $364 \mathrm{~kW}$ 의 n-heptane을 가연물로 이용하였으며, $0.5 \mathrm{~m}$ 부터 $0.05 \mathrm{~m}$ 까지 격자의 크 기를 좁혀가며 시뮬레이션을 수행하였다. 시률레이션 시작 후 $180 \mathrm{~s}$ 시점에서 바닥으로부터 $1.1 \mathrm{~m}$ 의 높이에서 온도를 측정하여 측정 온도가 안정화되는 시점의 격자크기를 열감 지 시뮬레이션의 격자크기로 선정하였다.

Figure 2는 훈소의 격자민감도 시뮬레이션의 결과로써 격자크기에 따른 연기농도의 변화를 나타낸 것이다. Figure 2 에서 보는 것과 같이 격자의 크기가 작아질수록 연기농도 
Table 1. Input Parameters for Grid Sensitivity Simulation

\begin{tabular}{c|c|c}
\hline & $\begin{array}{c}\text { Smoke Detection } \\
\text { Simulation }\end{array}$ & $\begin{array}{c}\text { Heat Detection } \\
\text { Simulation }\end{array}$ \\
\hline \hline Ignition Source & $1,000{ }^{\circ} \mathrm{C}$ Ignitor & $364 \mathrm{~kW}$ \\
\hline Combustibles & Cotton Wicks & N-heptane \\
\hline $\begin{array}{c}\text { Size of } \\
\text { Combustibles }\end{array}$ & $\begin{array}{c}0.2 \mathrm{~m}(\mathrm{X}) \times 0.2 \mathrm{~m} \\
(\mathrm{Y}) \times 0.4 \mathrm{~m}(\mathrm{Z})\end{array}$ & $\begin{array}{c}0.4 \mathrm{~m}(\mathrm{X}) \times 0.4 \mathrm{~m} \\
(\mathrm{Y}) \times 0.1 \mathrm{~m}(\mathrm{Z})\end{array}$ \\
\hline $\begin{array}{c}\text { Value of } \\
\text { Measurement }\end{array}$ & $\begin{array}{c}\text { Smoke Density } \\
(\% / \mathrm{m})\end{array}$ & Temperature $\left({ }^{\circ} \mathrm{C}\right)$ \\
\hline $\begin{array}{c}\text { Point of } \\
\text { Measurement }\end{array}$ & $3.6 \mathrm{~m}$ from Bottom & $1.1 \mathrm{~m}$ from Bottom \\
\hline $\begin{array}{c}\text { Time of } \\
\text { Measurement }\end{array}$ & $180 \mathrm{~s}$ after Ignition & $180 \mathrm{~s}$ after Ignition \\
\hline
\end{tabular}

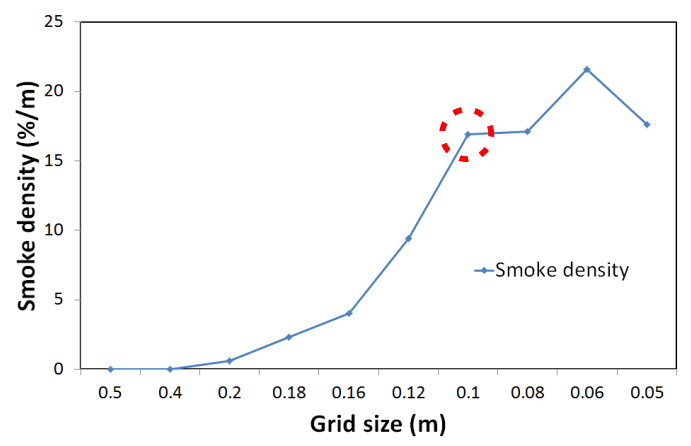

Figure 2. Smoke density according to grid size.

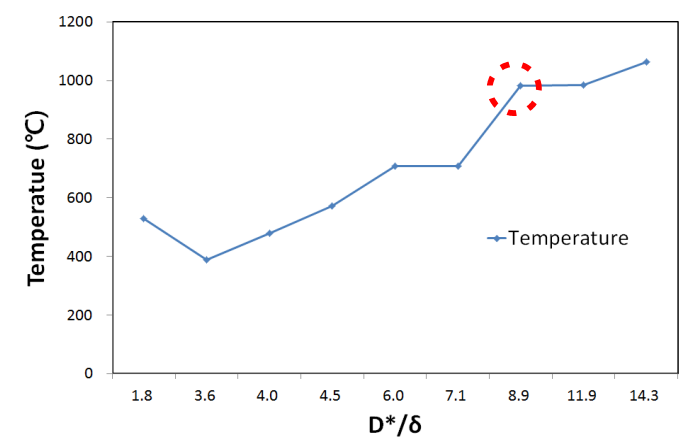

Figure 3. Temperature according to grid resolution.

가 높게 측정되었으며, 격자의 크기가 $0.1 \mathrm{~m}$ 시점부터 측정 된 연기농도가 안정화되는 것을 확인할 수 있다.

Figure 3은 화염화재의 격자민감도 시뮬레이션의 결과로 써 무차원특성길이에 대한 격자크기의 비 $\left(\mathrm{D}^{*} / \delta\right)$ 에 따른 온 도변화를 나타낸 것이다. Figure 3에서 보는 것과 같이 $\mathrm{D}^{* /}$ $\delta$ 값이 커질수록 온도가 높게 측정되었으며, $\mathrm{D}^{*} / \delta$ 가 8.9 이 상에서 온도가 크게 상승하지 않고 안정화되는 것을 확인 할 수 있다. 화염화재의 격자민감도 시뮬레이션에서 $\mathrm{D}^{* / \delta}$ 값이 8.9 인 격자의 크기는 $0.08 \mathrm{~m}$ 이다.

Table 2는 훈소와 화염화재 격자민감도 시뮬레이션의 결 과를 나타낸 것이다. 훈소와 화염화재의 격자민감도 시뮬
Table 2. Results of Grid Sensitivity Analysis

\begin{tabular}{c|c|c|c}
\hline & $\begin{array}{c}\text { Ignition } \\
\text { Source }\end{array}$ & $\begin{array}{c}\text { Grid Size } \\
(\mathrm{m})\end{array}$ & $\begin{array}{c}\text { Grid Resolution } \\
\left(\mathrm{D}^{*} / \delta\right)\end{array}$ \\
\hline \hline Smoldering & $\begin{array}{c}1,000{ }^{\circ} \mathrm{C} \\
\text { Ignitor }\end{array}$ & 0.1 & - \\
\hline Flame Fire & $\begin{array}{c}\text { N-heptane } \\
364 \mathrm{~kW}\end{array}$ & 0.08 & 8.9 \\
\hline
\end{tabular}

레이션의 결과로 볼 때, 훈소의 경우 $0.1 \mathrm{~m}$, 화염화재의 경 우 $0.08 \mathrm{~m}$ 가 가장 합리적인 격자크기로 판단된다.

\section{3 시나리오 및 입력조건}

본 연구에서 수행한 화재시뮬레이션은 면심지에 의한 훈소와 n-heptane에 의한 화염화재에 대하여 각각의 화원에 서 발생된 연기와 열기류의 유동을 분석하고, 조기 화재감 지를 위한 최적 화재감지 방법을 도출하기 위한 것이다. 각 각의 화원에서 발생된 연기와 열기류의 조기 화재감지를 위한 최적 화재감지기의 설치 조건을 분석하기 위하여 연 기감지 시뮬레이션과 열감지 시뮬레이션으로 구분하여 수 행하였다.

자동화재탐지설비 및 시각경보장치의 화재안전기준에서 광전식 1 종 또는 2 종 감지기의 경우 $8 \mathrm{~m}$ 이상 $15 \mathrm{~m}$ 이하에 서 적응성이 있는 것으로 규정하고 있다. 약 $15 \mathrm{~m}$ 높이에 설치된 광전식 감지기의 높이 적절성을 확인하고, 확인된 문제점에 대한 개선책을 도출하기 위하여 본 시뮬레이션에 서는 $4.0 \mathrm{~m}(\mathrm{X}) \times 4.0 \mathrm{~m}(\mathrm{Y}) \times 14.0 \mathrm{~m}(\mathrm{Z})$ 의 시률레이션 공 간을 구성하고, 시뮬레이션 공간 내에 $2.5 \mathrm{~m}(\mathrm{X}) \times 3.1 \mathrm{~m}$ $(\mathrm{Y}) \times 13.5 \mathrm{~m}(\mathrm{Z})$ 크기의 4 단 랙크 구조물과 천장을 모델링 하였다. 4단 랙크 구조물의 1 단은 바닥에서 $1 \mathrm{~m}$ 높이에 위 치시켰으며, 1 단의 전면과 후면에는 철재더미를 위치시키 고, 2 단부터 4단까지의 전면과 후면에는 $1.2 \mathrm{~m}(\mathrm{X}) \times 1.2 \mathrm{~m}$ $(\mathrm{Y}) \times 2.1 \mathrm{~m}(\mathrm{Z})$ 크기의 스티로폼이 내장된 골판지 표면 가 연물을 위치시켰다. 훈소에 의한 연기감지 시뮬레이션의 경우 격자의 크기를 $0.1 \mathrm{~m}$ 를 적용하여 총 224,000 개의 격자 로 구성하였으며, $0.2 \mathrm{~m}(\mathrm{X}) \times 0.2 \mathrm{~m}(\mathrm{Y}) \times 0.4 \mathrm{~m}(\mathrm{Z})$ 크기 의 면심지에 $1,000{ }^{\circ} \mathrm{C}$ Ignitor를 접촉시켜 연기를 발생시켰 다. 화염화재에 의한 열감지 시뮬레이션의 경우 $0.08 \mathrm{~m}$ 의 격자크기를 적용하여 총 437,500 개의 격자로 구성하였으 며, $0.4 \mathrm{~m}(\mathrm{X}) \times 0.4 \mathrm{~m}(\mathrm{Y}) \times 0.1 \mathrm{~m}(\mathrm{Z})$ 크기의 화조에 n-heptane을 가연물로 사용하여 열기를 발생시켰다. 시뮬레 이션의 Mesh 경계는 바닥의 경우 INERT, 측면과 상부의 5 개면은 $\mathrm{OPEN}$ 으로 설정하였으며, 초기 온도는 $20{ }^{\circ} \mathrm{C}$ 로 설정 하였다. 그리고 랙크 각 단의 상부와 천장에 온도센서, 연기 농도 측정이 가능한 연기감지기, 정온식감지기를 각각 9개씩 설치하였으며, 공기흡입형 감지기의 공기흡입구(Sampler)를 천장과 우측면에 각각 3 개씩 위치시켰다. Figure 4는 연기감 지 시뮬레이션과 열감지 시뮬레이션의 모델링과 센서의 배 치도를 나타낸 것이다. 


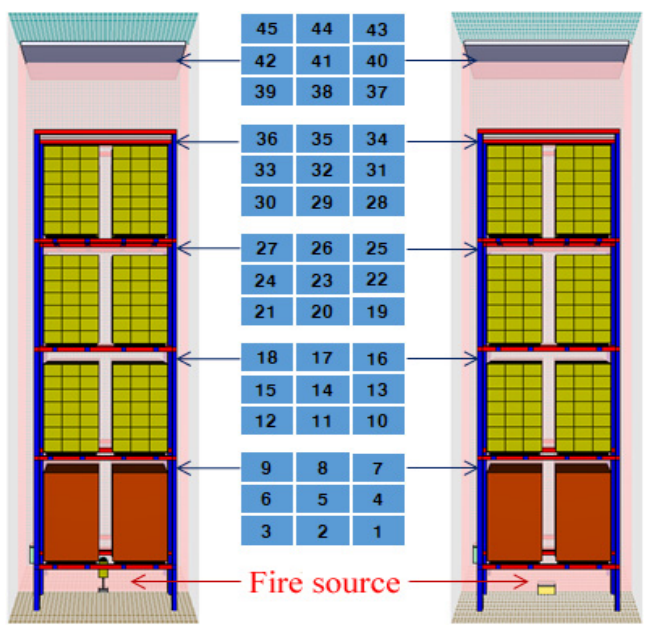

(a) Smoldering

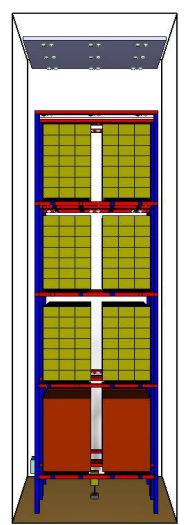

(a) $10 \mathrm{~s}$

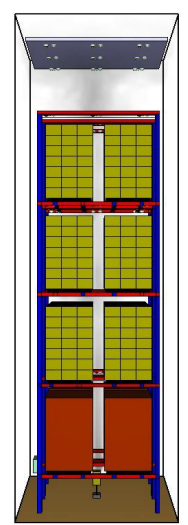

(b) $60 \mathrm{~s}$

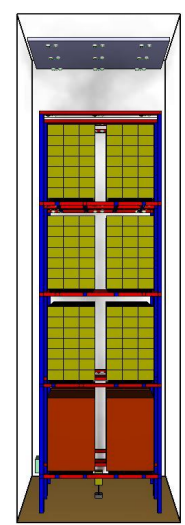

(c) $180 \mathrm{~s}$

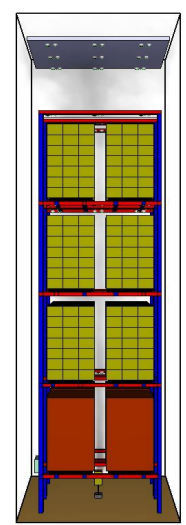

(d) $300 \mathrm{~s}$

Figure 5. Smoke diffusion of the smoke detection simulation.

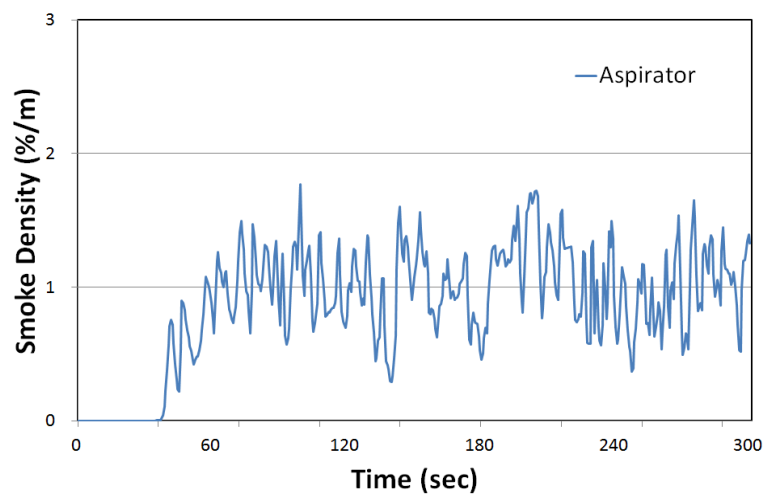

Figure 6. Smoke density according to time for air sampling smoke detector.

것이다. Figure 5는 연기감지 시뮬레이션 과정 중 시간에 따른 연기의 발생상황을 나타낸 것이다. 바닥에서 발생된 연기는 시뮬레이션 시작 후 약 $60 \mathrm{~s}$ 경 천장까지 도달하였 으며, 최상부에 도달한 연기는 천장과 측면의 OPEN면으로 배출되었다.

Figure 6은 공기흡입형 감지기에 의해 측정된 시간에 따

Table 3은 연기와 열기류의 조기화재 감지를 위한 최적 화재감지기 설치조건을 분석하기 위한 연기감지 시뮬레이 션과 열감지 시뮬레이션의 입력조건을 나타낸 것이다. 위에 서 언급한 바와 같이 연기감지 시률레이션의 가연물은 면심 지를 사용하였고, 열감지 시뮬레이션의 가연물은 n-heptane 을 사용하였으며, 총 시률레이션의 구동시간은 $300 \mathrm{~s}$ 로 설정 하였다.

\section{3. 결과 및 고찰}

\section{1 연기감지 시뮬레이션}

본 연구에서 수행한 연기감지 시뮬레이션은 면심지의 훈소에 의해 발생된 연기의 유동을 분석하고, 화재의 조기 감지를 위한 화재감지기의 최적 설치조건을 확인하기 위한

른 연기농도를 나타낸 것이다. 공기흡입형 감지기의 화재 감지 설정농도를 $1 \% / \mathrm{m}$ 로 설정하는 경우 시뮬레이션 시작 후 약 $62 \mathrm{~s}$ 경과 후에 설정농도에 도달하는 것으로 나타났 다. 공기흡입형 감지기의 경우 설정농도를 낮게 설정하면 랙크식 창고에서 발생되는 연기의 조기감지에 적합할 수 있다. 하지만 화재 설정농도 값에 따라 화재의 조기감지 유 효성에 차이가 발생될 수 있으며, 설정농도를 낮게 설정하 는 경우 비화재보의 문제가 발생될 수 있다. 따라서 비화재 보의 문제를 해결하지 못한다면 랙크식 창고에서 조기 화 재감지 측면에서 적합하지 않을 수 있다.

Figure 7은 랙크 각 단의 상부에서 측정한 연기농도의 최 대값을 나타낸 것이다. 각 단에서 화원의 직상부에 위치한 중앙 지점에서 가장 높은 연기농도가 측정되었다. 1 단에서 는 화원의 직상부에 위치한 5 번 연기센서에서 약 $47 \% / \mathrm{m}$ 까 


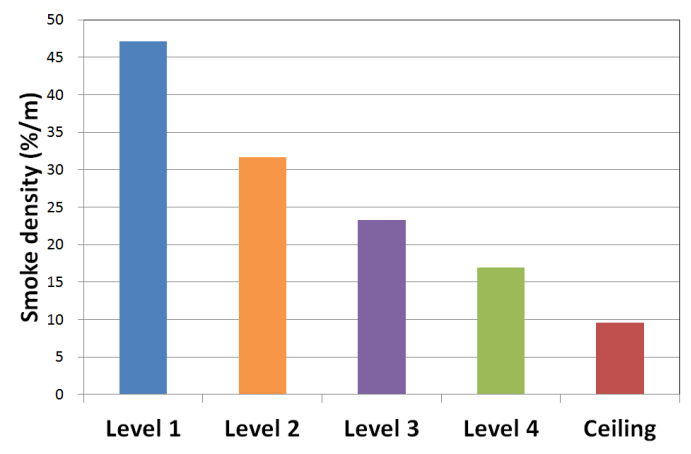

Figure 7. Maximum value of smoke density in each rack.

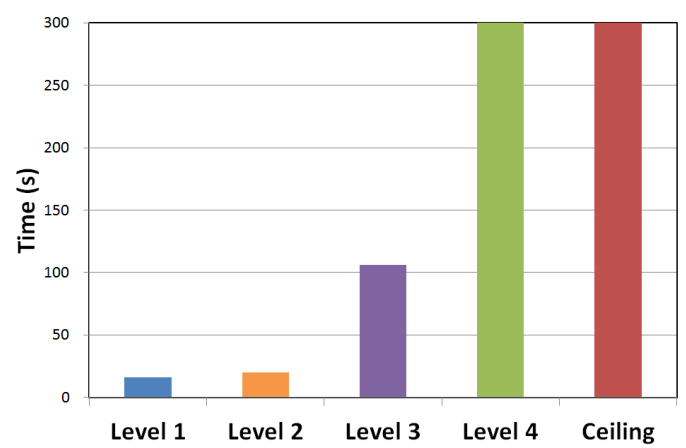

Figure 8. The time required to reach smoke density of $20 \% / \mathrm{m}$ in each rack.

지 측정되었으며, 2 단은 약 $32 \% / \mathrm{m}, 3$ 단은 약 $23 \% / \mathrm{m}, 4$ 단 은 약 $17 \% / \mathrm{m}$, 천장은 약 $9 \% / \mathrm{m}$ 까지 측정되었다. 각 단의 상부에서 연기감지기에 의해 연기를 명확히 감지할 수 있 는 최대 연기농도를 $20 \% / \mathrm{m}$ 라 할 때, 본 시뮬레이션의 결 과 랙크의 3 단 이내에 연기감지기를 설치해야 화재 시 발 생되는 연기의 조기감지가 가능할 것으로 판단된다.

Figure 8 은 랙크의 각 단에서 $20 \% / \mathrm{m}$ 의 농도까지 측정되 는데 소요되는 시간을 나타낸 것이다. 1단의 경우 시률레 이션 시작 후 $16 \mathrm{~s}$ 가 소요되었고, 2단은 $20 \mathrm{~s}, 3$ 단은 $106 \mathrm{~s}$ 가 소요되었다. 하지만 4 단과 5 단의 상부에 설치된 감지기는 시뮬레이션 종료 시점인 $300 \mathrm{~s}$ 까지 목표 연기농도인 20 $\% / \mathrm{m}$ 까지 측정되지 못하는 것으로 나타났다. 본 연기감지 시뮬레이션의 결과를 보면 랙크의 1 단 높이를 $2.5 \mathrm{~m}$ 기준 으로 하고, 화재의 조기감지 조건을 화재발생 후 $120 \mathrm{~s}$ 이 내에 감지하는 것으로 볼 때 랙크의 3 level 마다 연기감지 기를 설치해야 화재 시 발생되는 연기의 조기감지가 가능 한 것을 알 수 있다.

\section{2 열감지 시뮬레이션}

열감지 시뮬레이션은 실제 화재를 모사하여 n-heptane의 연소로 인해 발생되는 열기류의 유동현상을 분석하고, 열기 류의 조기감지를 위한 최적 화재감지기 설치조건을 확인하 기 위한 것이다. 4 단 랙크 구조물의 바닥 중앙에서 n-heptane

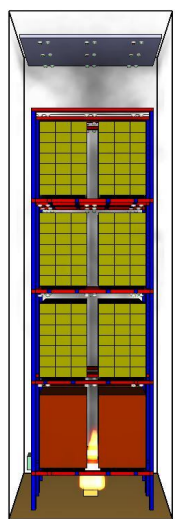

(a) $10 \mathrm{~s}$

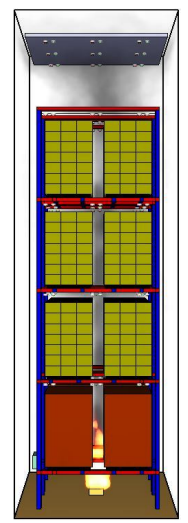

(b) $60 \mathrm{~s}$

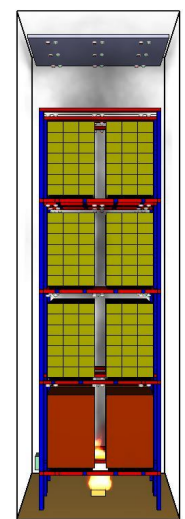

(c) $180 \mathrm{~s}$

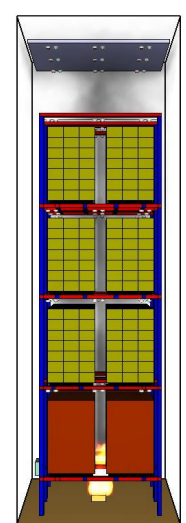

(d) $300 \mathrm{~s}$
Figure 9. Smoke and heat diffusion of the heat detection simulation.

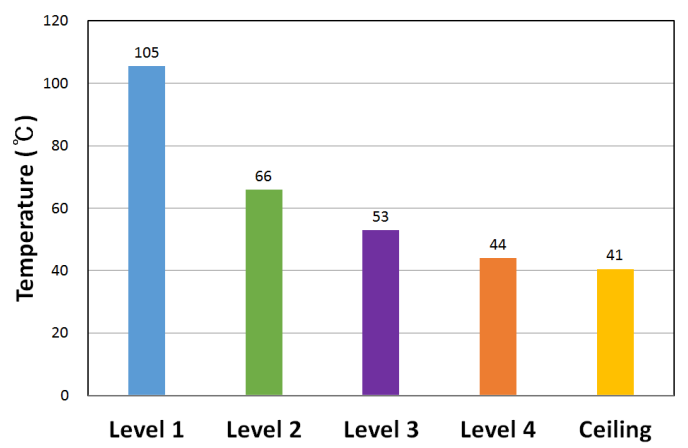

Figure 10. Maximum value of measured temperature in each rack.

$364 \mathrm{~kW}$ 화원에 의해 열기류를 발생시킨 후 랙크 각 단의 상 부와 천장에 설치된 열감지기와 온도센서를 이용하여 열기 류의 유동을 분석하였다. Figure 9는 시뮬레이션 구동 시간 인 $300 \mathrm{~s}$ 동안 시간에 따른 열감지 시뮬레이션의 진행과정 을 나타낸 것이다.

Figure 10은 랙크 각 단의 상부에서 측정된 온도의 최고 값을 나타낸 것이다. 1 단의 경우 화원의 직상부인 중앙에 위치한 온도센서에서 가장 높은 온도가 측정되었으며, 측 면에 위치한 온도센서에서는 비교적 낮은 온도가 측정되었 다. 또한 측정 위치가 높을수록 측정온도는 급격히 낮아지 는 경향을 나타냈으며, 각 단의 측정지점에서 온도차이는 좁혀지는 경향을 나타냈다. 1 단의 경우 화원의 직상부에서 최고온도가 약 $105{ }^{\circ} \mathrm{C}$ 까지 측정되었고, 2 단은 약 $66{ }^{\circ} \mathrm{C}, 3$ 단 은 약 $53{ }^{\circ} \mathrm{C}, 4$ 단은 약 $44{ }^{\circ} \mathrm{C}$, 천장은 약 $41{ }^{\circ} \mathrm{C}$ 까지 측정되었 다. Figure 10 의 결과로 볼 때 공칭작동온도가 $70{ }^{\circ} \mathrm{C}$ 인 정온 식감지기의 경우 1 단을 제외한 2 단 이상의 위치에서는 적 응성이 없는 것을 알 수 있다.

Figure 11은 랙크 각 단의 상부에서 측정한 분당 온도상 승률 $\left({ }^{\circ} \mathrm{C} / \mathrm{m}\right)$ 을 나타낸 것이다. 시뮬레이션 시작 후 2 분을 기 준으로 분당 온도상승률을 측정하였다. 1 단의 경우 $39.9{ }^{\circ} \mathrm{C}$ $/ \mathrm{m}$ 의 분당 온도상승률을 나타냈고, 2 단은 $22.2^{\circ} \mathrm{C} / \mathrm{m}, 3$ 단은 $16.5^{\circ} \mathrm{C} / \mathrm{m}, 4$ 단은 $1.4{ }^{\circ} \mathrm{C} / \mathrm{m}$, 천장은 $9.5^{\circ} \mathrm{C} / \mathrm{m}$ 의 분당 온도상 


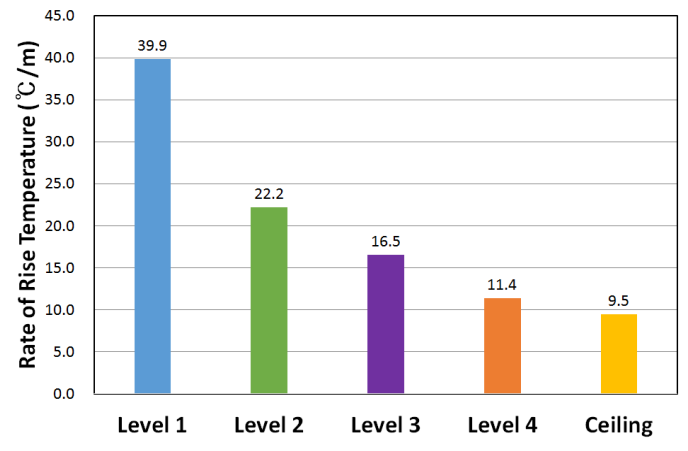

Figure 11. Rate of temperature rise increase per min in each rack.

승률을 나타냈다. 차동식 감지기의 경우 1 종은 $10{ }^{\circ} \mathrm{C} / \mathrm{m}$ 이 상의 온도상승률에서 작동하며, 2 종은 $15{ }^{\circ} \mathrm{C} / \mathrm{m}$ 이상의 온 도상승률에서 작동한다. Figure 11의 결과로 볼 때 차동식 감지기 1 종의 경우 랙크의 4단 이내, 2 종의 경우 랙크의 3 단 이내에 설치해야 열기류의 조기감지가 가능할 것으로 판단된다.

\section{4. 결 론}

본 연구는 수치해석 프로그램인 FDS를 이용하여 4단 랙 크 구조물에서 화재 시 발생되는 연기와 열기류의 유동을 분석하고, 랙크식 창고에서 화재의 조기감지를 위한 화재 감지기의 최적 설치조건에 대하여 분석한 것이다. 본 시뮬 레이션을 통해 랙크식 창고에서 화재의 조기감지를 실현하 기 위하여 다음과 같은 결론을 도출하였다.

첫째, 랙크식 창고는 층고가 높고, 적재된 가연물에 의해 화재발생 시 발생되는 연기와 열기류가 차단되기 때문에 조기에 화재를 감지하기 위하여 랙크의 천장이 아닌 중간 level에 화재감지기를 설치해야 한다.

둘째, 랙크식 창고에서 발생되는 화재를 조기에 감지하 기 위하여 열과 연기를 복합적으로 감지할 필요가 있으며, 열과 연기의 복합적인 감지가 가능한 열 - 연기 복합형 감 지기를 랙크에 설치하는 경우 3 level 마다 설치해야 조기 감지 목적을 달성할 수 있을 것으로 사료된다.

셋째, 정온식 감지기는 주위온도가 공칭작동온도까지 상 승한 후 일정시간 지나야 작동되는 열적 지연이 있어 층고 가 높고 적재된 물품으로 인하여 열기류 유동이 차단되는 랙크식 창고에는 적응성이 낮다.

넷째, 차동식 감지기는 국내에서 가장 많이 사용되는 2 종을 기준으로 할 때 랙크의 3 level 마다 설치하면 조기감
지 목적을 달성할 수 있을 것으로 사료된다.

\section{후 기}

본 연구는 소방청 현장중심형 소방활동지원 기술개발사 업(MPSS-소방안전-2015-67)의 연구비 지원으로 수행되었 습니다.

\section{References}

1. J. A. Choi, "Fire Modeling and Smoking Control Characteristic Analysis of Electric Roon by Using FDS", Journal of the Korea Academia-Industrial cooperation Society, Vol. 19, No. 3, pp. 662-668 (2018).

2. W. H. Park, "Sensing Characteristics of Fire Detectors in Railway Tunnel by Using Numerical Analysis", Journal of the Korea Academia-Industrial cooperation Society, Vol. 16, No. 11, pp. 7964-7970 (2015).

3. K. O. Choi, "A Study on the Optimization of a Fire Detection and Suppression System for Domestic Rack-Type Warehouses", Ph.D. Dissertation, Gachon University, pp. 14-20 (2019).

4. S. B. Choi, "A Study on Fire Characteristics of Pilotis whit Urban Lifestyle Housing Buildings", Ph.D. Dissertation, Gachon University, pp. 104-107 (2017).

5. G. H. Go, "Estimation of FDS Prediction Performance on the Operation of Water-Mist", Journal of the Korea AcademiaIndustrial cooperation Society, Vol. 15, No. 8, pp. 48094814 (2014).

6. NUREG 1824, "Verification and Validation of Selected Fire Models for Nuclear Power Plant Applications", EPRI 1011999, Final Report (2007).

7. National Fire Safety Code 203, "National Fire Safety Code for Automatic Fire Alarm System" (2017).

8. K. S. Kim, "Evaluation of the Appropriateness of Smoke Control Conditions of Platform at the Subway Fire by using FDS", Fire Science and Engineering, Vol. 27, No. 5, pp. 8-14 (2013).

9. G. H. Go, "Estimation of FDS Prediction Performance on the Operation of Water-Mist", Journal of the Korea AcademiaIndustrial cooperation Society, Vol. 15, No. 8, pp. 48094814 (2014). 